\title{
Elk Monitoring Report for Calendar Year 2012
}

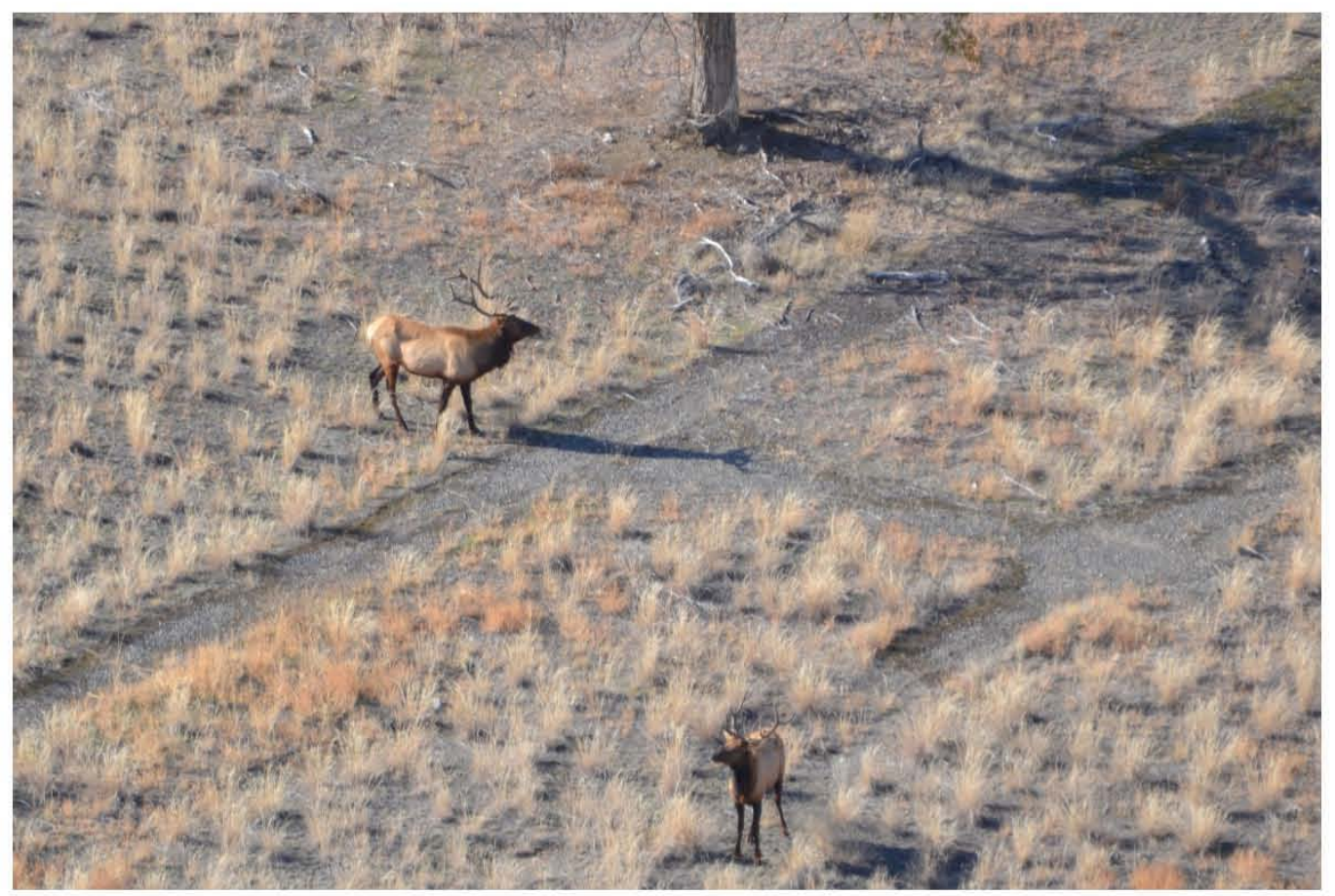

Prepared for the U.S. Department of Energy Assistant Secretary for Environmental Management

Contractor for the U.S. Department of Energy under Contract DE-AC06-09RL14728

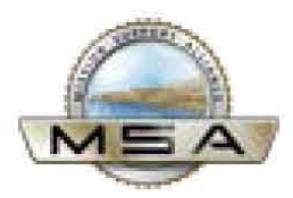

P.O. Box 650

Richland, Washington 99352 
HNF-54666

Revision 0

TRADEMARK DISCLAIMER

Reference herein to any specific commercial product, process, or service by trade name, trademark, manufacturer, or otherwise, does not necessarily constitute or imply its endorsement, recommendation, or favoring by the United States Government or any agency thereof or its contractors or subcontractors.

This report has been reproduced from the best available copy.

Printed in the United States of America

The cover photo is courtesy of Cole Lindsey. 


\section{Elk Monitoring Report for Calendar Year 2012}

C. Lindsey, B. Tiller, J. Nugent, and J. Wilde Mssion Support Alliance

Date Publisted

March 2013

Prepared for the U.S. Department of Energy

Assistant Secretary for Environmental Management

Contractor for the U.S. Department of Energy

under Contract DE-AC06-09RL14728

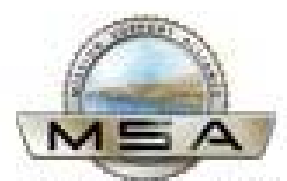

P.0. Box 650

Richland, Was hington 99352 
HNF-54666

Revision 0

This page intentionally left blank. 


\section{Contents}

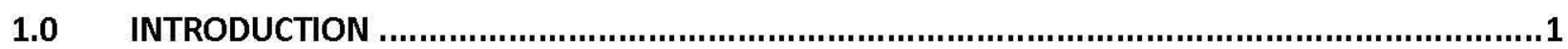

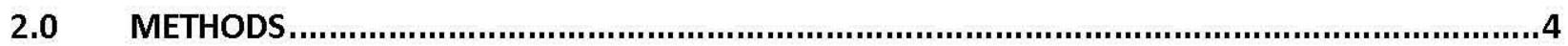

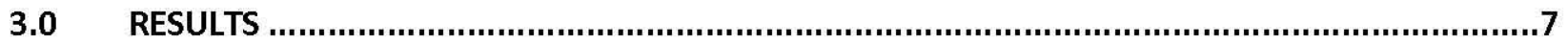

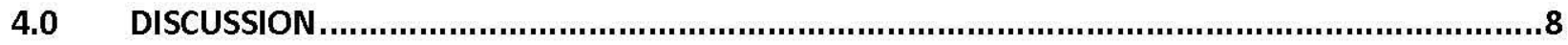

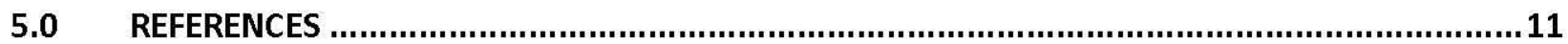

\section{Figures}

Figure 1. Areas traditionally used by the RHEH (taken from Tiller et al. 2000) ....................................... 1

Figure 2. Bachelor herd of bulls observed on central Hanford near the old Hanford Townsite................. 2

Figure 3. WDFW/FWS aerial elk survey units that occur on DOE-RL managed property......................... 4

Figure 4. Search area and route used for MSA aerial elk surveys ................................................... 5

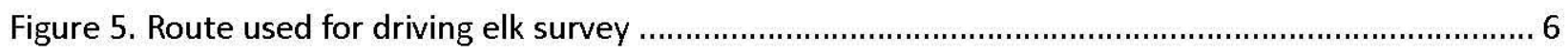

Figure 6. Optimal and sub-optimal viewing conditions during an aerial survey with patchy cloud

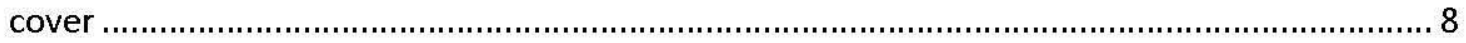

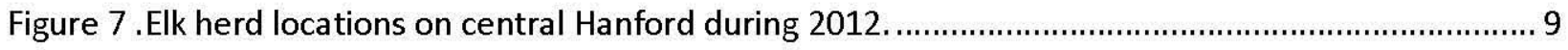

Figure 8. Maximum total elk counts for the WDFW/FWS counts and the 2012 MSA elk survey on central Hanford

\section{Tables}

Table 1. Data from 2004-2011 winter counts for from the Rattlesnake Hills Elk Herd (Newsome 2011) 3

Table 2. Elk counted, by unit, on central Hanford by WDFW/FWS during winter aerial surveys 3

Table 3. Elk observed during MSA surveys or incidentally by field staff during 2012 7 


\subsection{Introduction}

Elk were first documented on the Hanford Site in 1972. Since then, the number of elk in this region has grown to peak at over 800 individuals (Tiller et al. 2000). This elk herd is relatively isolated from other elk herds in Washington State and, as such, has been identified by state wildlife managers as the Rattlesnake Hills Elk Herd (RHEH). The core range of the RHEH through the 1990's was limited to a portion of the Hanford Reach National Monument known as the Fitzner-Eberhardt Arid Lands Ecology Reserve (FEALE), and private lands to the south and west of FEALE (Figure 1, Tiller et al. 2000). Peripheral ranges for the RHEH included the central portions of the Hanford Site, the Rattlesnake Hills west of State Route 241, the Yakima Training Center, and southern Grant and western Franklin Counties (Newsome 2011). Until recently the central portion of the Hanford Site was used infrequently by the RHEH. Tiller et al. (2000) noted that "A single female elk was observed on central Hanford in 1997. From 1997 through 2000, only a few small herds of male (bull) elk (Figure 2) were documented using the central Hanford Site regions (Tiller et al. 2000). Beginning in approximately 2010, a herd of approximately 22 elk, often including cows, yearlings and a single adult bull began regularly occupying areas along the northern portion of central Hanford, in addition to the bachelor herds of bulls.

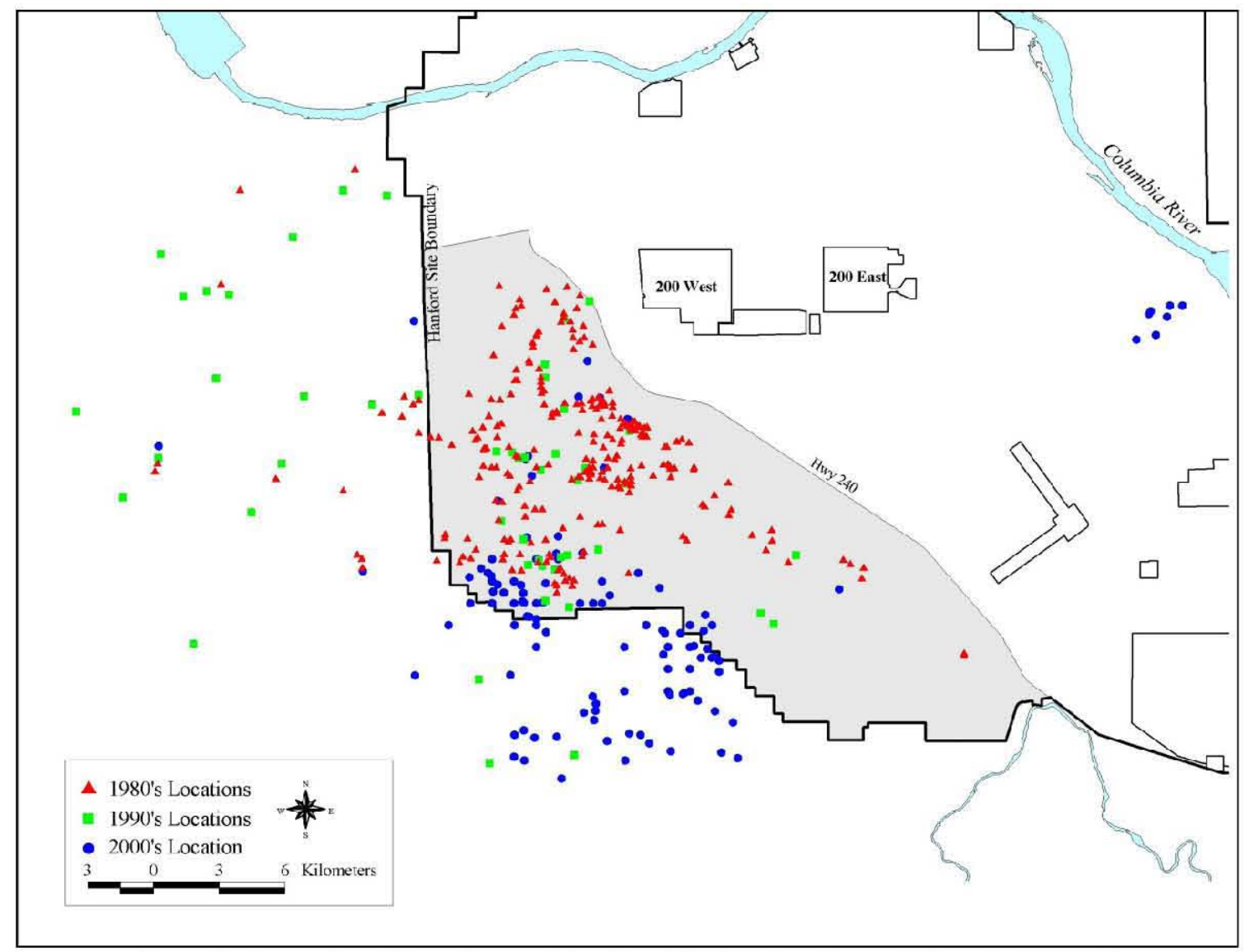

Figure 1. Areas traditionally used by the RHEH (taken from Tiller et al. 2000). 


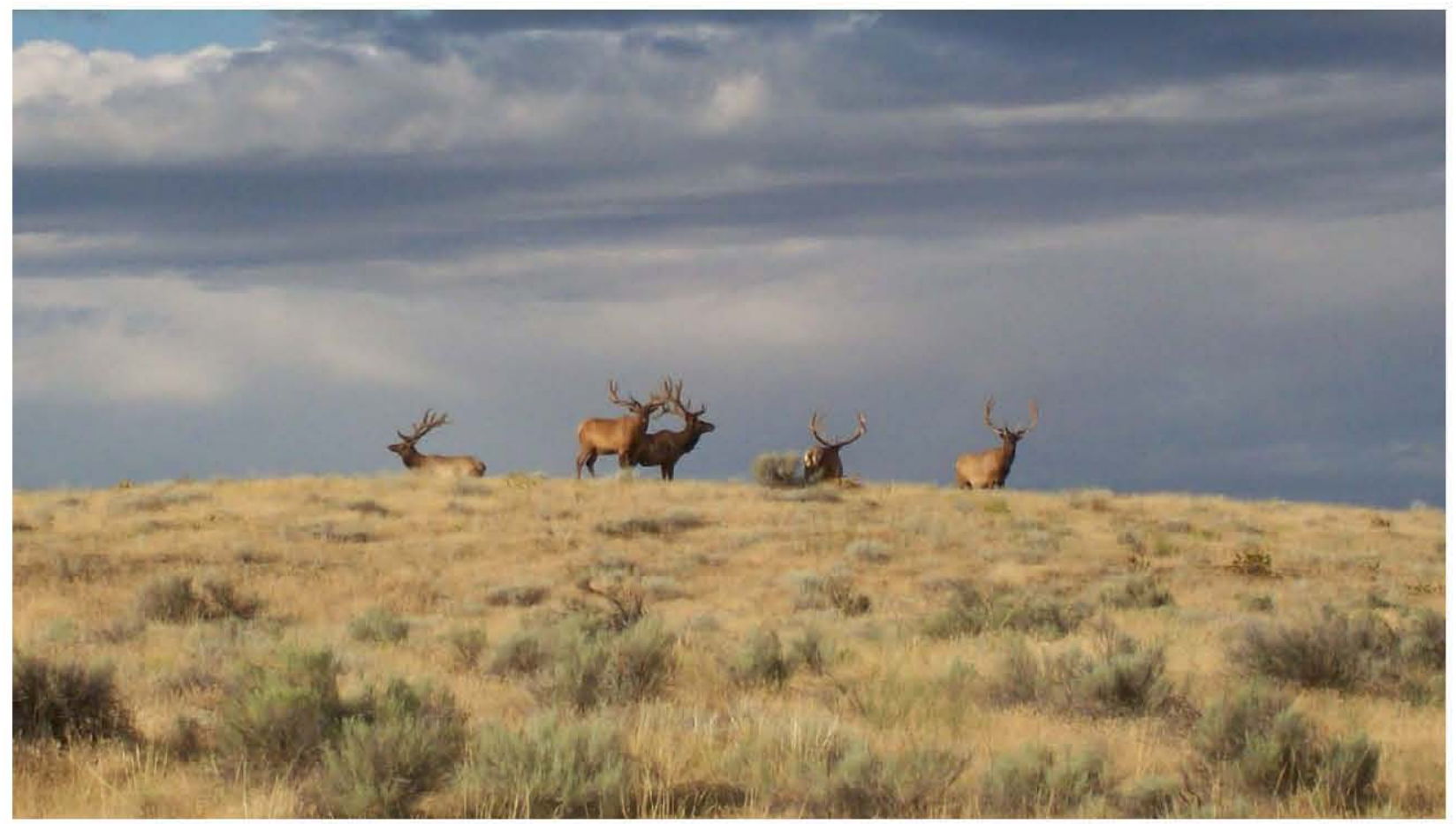

Figure 2. Bachelor herd of bulls observed on central Hanford near the old Hanford Townsite.

On December 1, 2011, the U.S. Fish and Wildlife Service (FWS) released a "Draft Hanford Reach National Monument Elk Population Control Hunt Plan" in an effort to reduce the RHEH elk herd size from its current level of approximately 772 animals to a population size of 350 animals (Newsome 2011). The Plan stated that hunting would be performed from the beginning of October through the end of March. The document also stated that "Disturbance from hunting could result in elk crossing Highway 240 and moving into the central portion of the Hanford Site" (Newsome 2011).

The U.S. Department of Energy's Richland Operations (DOE-RL) Public Safety and Resource Protection Program conducts elk monitoring efforts on the central portions of the Hanford Site to help document elk use areas and relative abundance, as well as possible changes in elk use patterns due to hunting on the FEALE. This report provides a summary of the elk survey results conducted during 2012 on the central portions of the Hanford Site.

The FWS and the Washington Department of Fish and Wildlife (WDFW) have conducted aerial surveys on the Hanford Site since 2004 (Newsome 2011). The data collected during these surveys is summarized in Table 1. These surveys are performed and analyzed using a transect-based sampling method, using a helicopter, and model called AERIAL SURVEY developed at University of Idaho. 
Table 1. Data from 2004-2011 winter counts for from the Rattlesnake Hills Elk Herd (Newsome 2011)

\begin{tabular}{|c|c|c|c|c|c|c|c|}
\hline \multirow[t]{2}{*}{ Winter } & \multirow{2}{*}{$\begin{array}{c}\text { Raw } \\
\text { Count }\end{array}$} & \multirow{2}{*}{$\begin{array}{l}\text { Herd Size Estimate } \\
\text { (Model Generated) }\end{array}$} & \multirow{2}{*}{$\begin{array}{c}90 \% \\
\text { confidence }\end{array}$} & \multirow{2}{*}{$\begin{array}{c}\text { Total Variance } \\
\left(\mathrm{SE}^{2}\right)\end{array}$} & \multicolumn{3}{|c|}{ Herd Composition } \\
\hline & & & & & $\%$ Cows & $\%$ Bulls & $\%$ Calves \\
\hline 2004/05 & 670 & 674 & 8 & 22 & 62 & 24 & 13 \\
\hline $2005 / 06$ & 533 & 537 & 7 & 18 & 53 & 27 & 19 \\
\hline $2006 / 07$ & 675 & 681 & 11 & 43 & 58 & 26 & 16 \\
\hline $2007 / 08$ & 510 & 639 & 240 & 21,345 & 53 & 26 & 22 \\
\hline $2008 / 09$ & 630 & 639 & 12 & 53 & 61 & 30 & 9 \\
\hline $2009 / 10$ & 671 & 677 & 11 & 42 & 59 & 30 & 11 \\
\hline $2010 / 11$ & 767 & 772 & 11 & 48 & 63 & 23 & 14 \\
\hline
\end{tabular}

FWS/WDFW counts are conducted in 17 units that are spread across the FEALE, central Hanford, and the McGee Riverlands portion of the Hanford Site. Of these 17 units, three are located on central Hanford (Figure 2). The total number of elk counted in the units on central Hanford since 2006 is shown in Table 2, while a map of the three units that fall onto the central portion of the Hanford Site is shown in Figure 2. From the data in Table 2, it is clear that elk activity on central Hanford is concentrated in Unit 6, between the Hanford Townsite, 100-F Area, and Gable Mountain. However, no surveys are conducted on central Hanford outside of the three units shown in Figure 3.

Table 2. Elk counted, by unit, on central Hanford by WDFW/FWS during winter aerial surveys

\begin{tabular}{|c|c|c|c|c|c|}
\hline Year & Cows & Calves & Spikes & Br Bulls & Total \\
\hline \multicolumn{6}{|c|}{ Unit 6} \\
\hline 2012 & 14 & 7 & 0 & 1 & 22 \\
\hline 2011 & 0 & 0 & 4 & 1 & 5 \\
\hline 2010 & 15 & 4 & 0 & 7 & 26 \\
\hline 2009 & 0 & 0 & 0 & 9 & 9 \\
\hline 2008 & 0 & 0 & 0 & 16 & 16 \\
\hline 2007 & 0 & 0 & 0 & 0 & 0 \\
\hline 2006 & 6 & 0 & 19 & 25 & 50 \\
\hline \multicolumn{6}{|c|}{ Unit 16} \\
\hline 2012 & 0 & 0 & 0 & 0 & 0 \\
\hline 2011 & n/a & $\mathrm{n} / \mathrm{a}$ & $\mathrm{n} / \mathrm{a}$ & $n / a$ & $n / a$ \\
\hline 2010 & 0 & 0 & 0 & 0 & 0 \\
\hline 2009 & $\mathrm{n} / \mathrm{a}$ & $\mathrm{n} / \mathrm{a}$ & $\mathrm{n} / \mathrm{a}$ & $n / a$ & $n / a$ \\
\hline 2008 & n/a & $\mathrm{n} / \mathrm{a}$ & $\mathrm{n} / \mathrm{a}$ & $n / a$ & $n / a$ \\
\hline 2007 & 0 & 0 & 0 & 0 & 0 \\
\hline 2006 & 0 & 0 & 0 & 0 & 0 \\
\hline \multicolumn{6}{|c|}{ Unit 17} \\
\hline 2012 & $\mathrm{n} / \mathrm{a}$ & $\mathrm{n} / \mathrm{a}$ & $\mathrm{n} / \mathrm{a}$ & $n / a$ & $\mathrm{n} / \mathrm{a}$ \\
\hline 2011 & $\mathrm{n} / \mathrm{a}$ & $\mathrm{n} / \mathrm{a}$ & $\mathrm{n} / \mathrm{a}$ & $n / a$ & $n / a$ \\
\hline 2010 & $n / a$ & $\mathrm{n} / \mathrm{a}$ & $\mathrm{n} / \mathrm{a}$ & $n / a$ & $n / a$ \\
\hline 2009 & 0 & 0 & 0 & 0 & 0 \\
\hline 2008 & $\mathrm{n} / \mathrm{a}$ & $\mathrm{n} / \mathrm{a}$ & $\mathrm{n} / \mathrm{a}$ & $\mathrm{n} / \mathrm{a}$ & $\mathrm{n} / \mathrm{a}$ \\
\hline 2007 & 0 & 0 & 0 & 0 & 0 \\
\hline 2006 & 0 & 0 & 0 & 0 & 0 \\
\hline
\end{tabular}




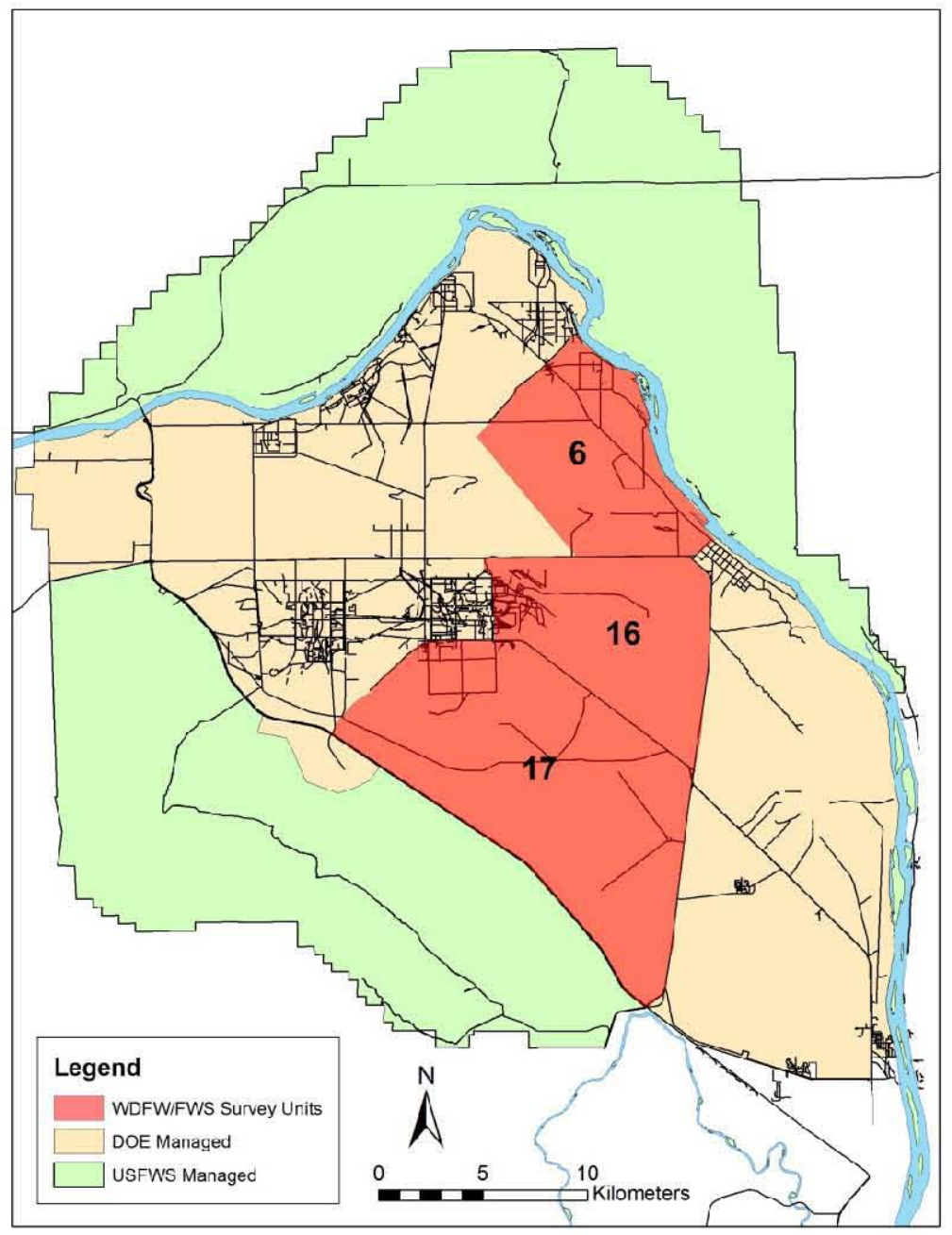

Figure 3. WDFW/FWS aerial elk survey units that occur on DOE-RL managed property

\subsection{Methods}

Aerial survey and driving survey methods were used for the central Hanford DOE-RL elk monitoring efforts. Surveys were conducted in the areas where elk have been documented in the past. The survey areas includes the three units in the WDFW/FWS aerial surveys as well as other contiguous areas west of unit 6 and east of units 6 and 1 (Figure 4). In addition, incidental observations of elk were documented between survey events. Aerial surveys were conducted from a Cessna 182 fixed-wing aircraft, performing a systematic grid spaced approximately 2 kilometers (1.24 miles) apart across the survey area. Survey elevation was approximately 1200 feet above ground level, and aircraft speed was approximately $120 \mathrm{mph}$ (193 kph). Two surveyors were onboard, in addition to the pilot, one surveyor on each side of the aircraft. Surveyors scanned the area on their respective side of the airplane, out to approximately 1000 meters ( 3281 feet). Once an elk herd was discovered, the aircraft circled in order to allow for an accurate count and for digital photographs to be taken. Photos were used to confirm counts and to better distinguish the age of each elk (i.e. cows versus calves) and sex ratio of the herd (i.e. bulls versus cows). Elk herd locations were recorded with a Global Positioning System (GPS) unit when the airplane was directly above the herd. 
HNF-54666

Revision 0

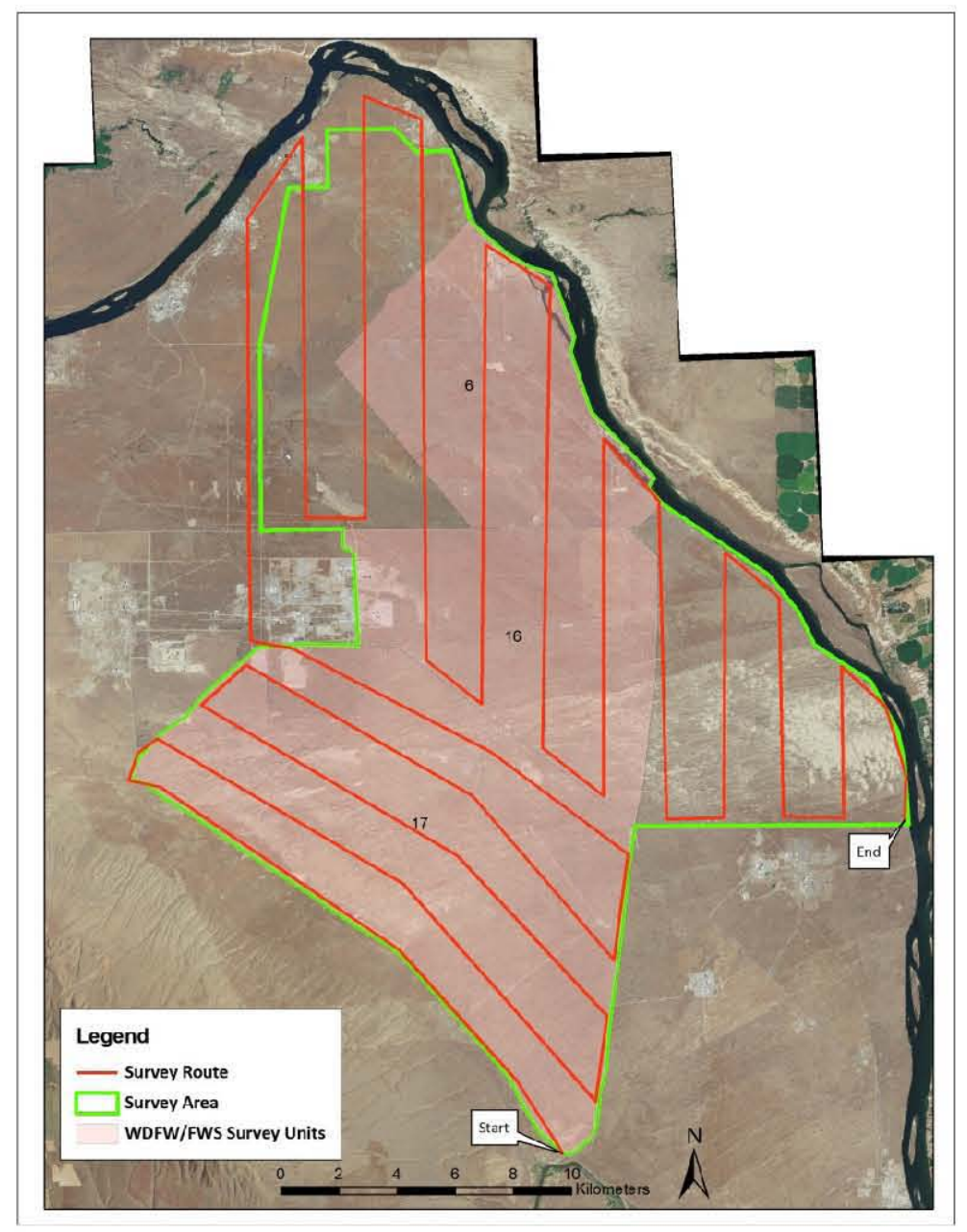

Figure 4. Search area and route used for MSA aerial elk surveys

Driving surveys consisted of traveling an established route (Figure 5) with two surveyors, one driver and one passenger. Driving speeds ranged from $10-20 \mathrm{mph}(12-32 \mathrm{kph})$ on unimproved roads, $20-30 \mathrm{mph}$ (32-48 kph)on paved roads, and posted speed limits on highways for safety purposes (e.g. $60 \mathrm{mph}$ [97 $\mathrm{kph}$ ). Surveyors scanned the areas visible from the established roadways and recorded the locations of any elk observed. Surveyors used binoculars, spotting scopes, and digital cameras to observe and document elk herds. Herd locations were approximated on paper maps and later digitized using a Geographic Information System (GIS). 


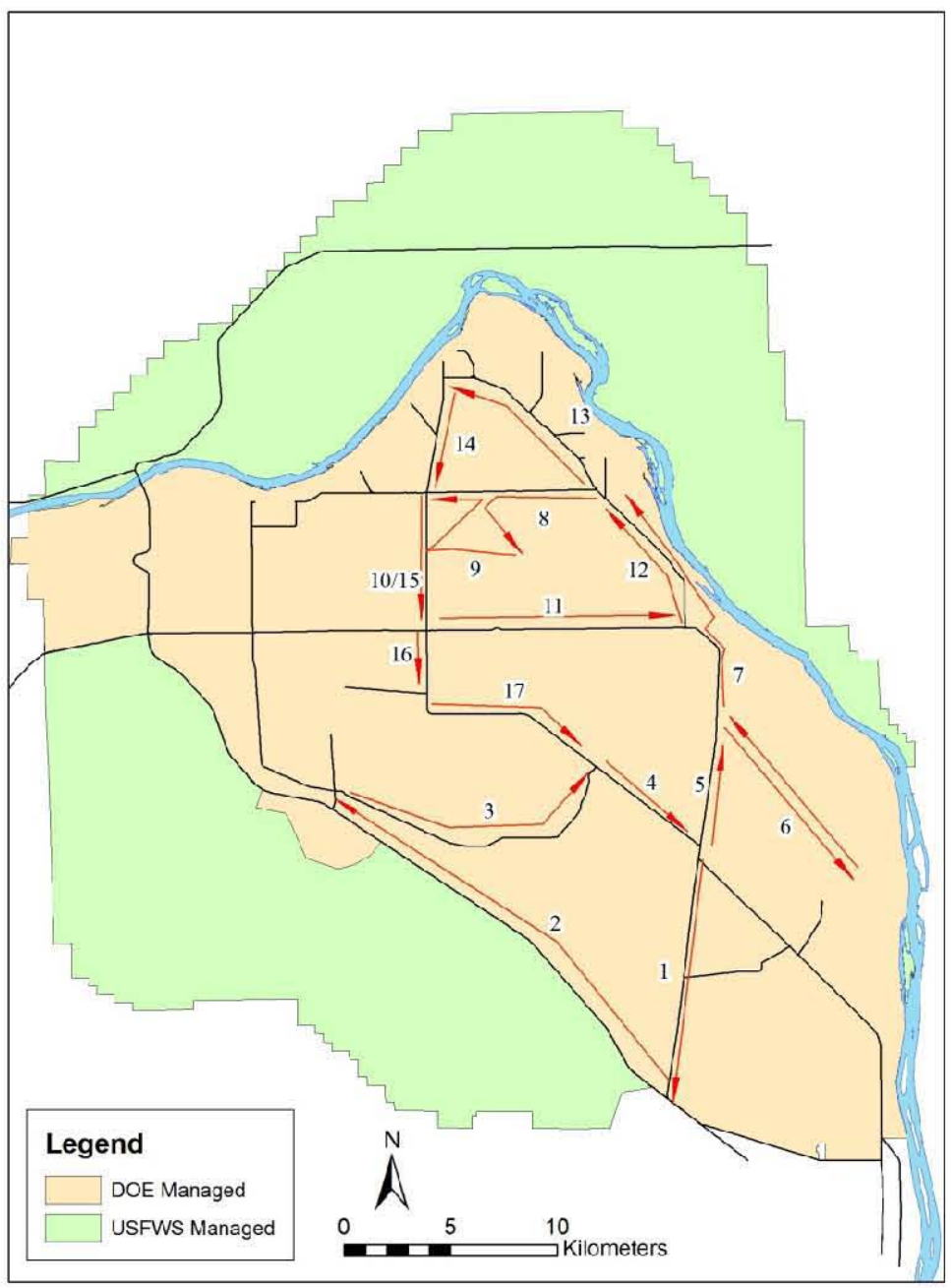

Figure 5. Route used for driving elk survey

Driving surveys were performed concurrently with aerial surveys. Aerial counts and driving counts could therefore be reconciled to assess detection differences between the two survey techniques, and to avoid double-counting herds. Due to the mostly treeless, open landscape of central Hanford, detection was expected to be high using the combined survey methods, therefore raw data was used to provide a relative abundance estimate for the survey area.

Elk surveys were scheduled to occur approximately quarterly (March-April, June-July, SeptemberOctober and November-December) to account for seasonal movements that elk may exhibit during different periods of the year, and consistent with the seasonal use patterns described by McCorquodale on the Hanford Site (McCorquodale et al. 1986 and Tiller et al. 2000). While elk are expected to be present on portions of central Hanford year-round, the highest numbers of elk using central Hanford have been documented during the winter and early spring periods (December -April) (Tiller et al. 2000). Surveys conducted during September-October represent the elk breeding-season, November-December and March-April survey seasons represent early- and late-wintering periods respectively, and June-July surveys represent the post-calving season. 


\subsection{Results}

Four complete surveys were conducted during 2012. The surveys were conducted on April 5, June 19, October 25, and December 18. During the first survey, conducted on April 5, the aerial survey crew detected 26 elk while the ground survey crew detected zero. For the June 19 survey, the aerial survey detected four elk not detected by the ground crew, while the ground crew detected 13 elk not detected by the aerial crew. A total of 17 elk were detected on June 19, 2012. On October 25, surveyors detected two herds of elk. Both the aerial and ground crews detected one herd of six, while only the ground crew detected the other herd of four. No elk were observed during the final survey, conducted on December 18.

Elk were observed incidentally, while personnel were conducting other projects, 12 times between March 27 and December 11, 2012. A summary of all elk observations is shown in Table 3.

Table 3. Elk observed during MSA surveys or incidentally by field staff during 2012

\begin{tabular}{|l|l|c|c|c|c|}
\hline \multicolumn{1}{|c|}{ Date } & \multicolumn{1}{c|}{ Survey Type } & Total Elk & Bulls & Cows & Calves \\
\hline $3 / 27 / 2012$ & Incidental Observation & 7 & $\mathrm{n} / \mathrm{a}$ & $\mathrm{n} / \mathrm{a}$ & $\mathrm{n} / \mathrm{a}$ \\
\hline $4 / 5 / 2012$ & Aerial & 26 & 1 & 25 & 0 \\
\hline $4 / 26 / 2012$ & Incidental Observation & 2 & 0 & 2 & 0 \\
\hline $5 / 1 / 2012$ & Incidental Observation & 2 & 2 & 0 & 0 \\
\hline $5 / 14 / 2012$ & Incidental Observation & 8 & 8 & 0 & 0 \\
\hline $5 / 17 / 2012$ & Incidental Observation & 3 & 0 & 3 & 0 \\
\hline $5 / 24 / 2012$ & Incidental Observation & 1 & 0 & 1 & 0 \\
\hline $5 / 31 / 2012$ & Incidental Observation & 1 & 0 & 1 & 0 \\
\hline $6 / 19 / 2012$ & Incidental Observation & 13 & $\mathrm{n} / \mathrm{a}$ & $\mathrm{n} / \mathrm{a}$ & $\mathrm{n} / \mathrm{a}$ \\
\hline $6 / 19 / 2012$ & Aerial & 4 & 0 & 4 & 0 \\
\hline $6 / 19 / 2012$ & Ground & 13 & 13 & 0 & 0 \\
\hline $10 / 10 / 2012$ & Incidental Observation & 1 & 1 & 0 & 0 \\
\hline $10 / 17 / 2012$ & Incidental Observation & 13 & 2 & $\mathrm{n} / \mathrm{a}$ & $\mathrm{n} / \mathrm{a}$ \\
\hline $10 / 25 / 2012$ & Aerial/Ground & 6 & 2 & 3 & 1 \\
\hline $10 / 25 / 2012$ & Ground & 4 & 0 & 4 & 0 \\
\hline $11 / 27 / 2012$ & Incidental Observation & 20 & 2 & 14 & 4 \\
\hline $12 / 11 / 2012$ & Incidental Observation & 37 & 1 & $\mathrm{n} / \mathrm{a}$ & $\mathrm{n} / \mathrm{a}$ \\
\hline $12 / 18 / 2012$ & Aerial/Ground & 0 & 0 & 0 & 0 \\
\hline Note: "n/a" is used when observers were unable to distinguish between classifications \\
\hline
\end{tabular}

As shown in the Table 3, the number of elk using central Hanford during 2012 was generally less than 40 individuals and appeared to primarily consist of 2 main elk herds. The main elk herd observed during the spring of 2012 consisted of approximately 26 individuals and was comprised largely of antlerless elk; this herd expanded later in the season to approximately 40 . A second elk herd consisting largely of bulls was observed on central portions of the Hanford Site intermittently throughout the year. 


\subsection{Discussion}

A total of four aerial/ground survey events were successfully completed during 2012. Inclement weather delayed several surveys, but surveys were rescheduled and still occurred during the selected time windows. Aerial survey quality was influenced by weather conditions. When surveys were performed on clear sunny days, visibility was excellent. On days with patchy or full cloud cover, visibility was suboptimal (Figure 5). Surveyors attempted to leave flexibility in the flight schedules to allow for weather related modifications. However, with several flights delayed due to high winds or other weather extremes, it became prohibitive to limit surveys exclusively to clear sunny days. Other factors affecting elk detection included sun aspect and vegetation color. Surveyors attempted to keep the sun behind them while searching for elk, looking forward out of the plane when flying north and looking backward when flying south toward sun. Finally, vegetation color, especially during the October survey, decreased detectability. As is shown in this report's cover photograph, the color of dried Russian thistle (Salsola kali) skeletons and native bunchgrasses were very similar to the color of elk pelage during the October survey.

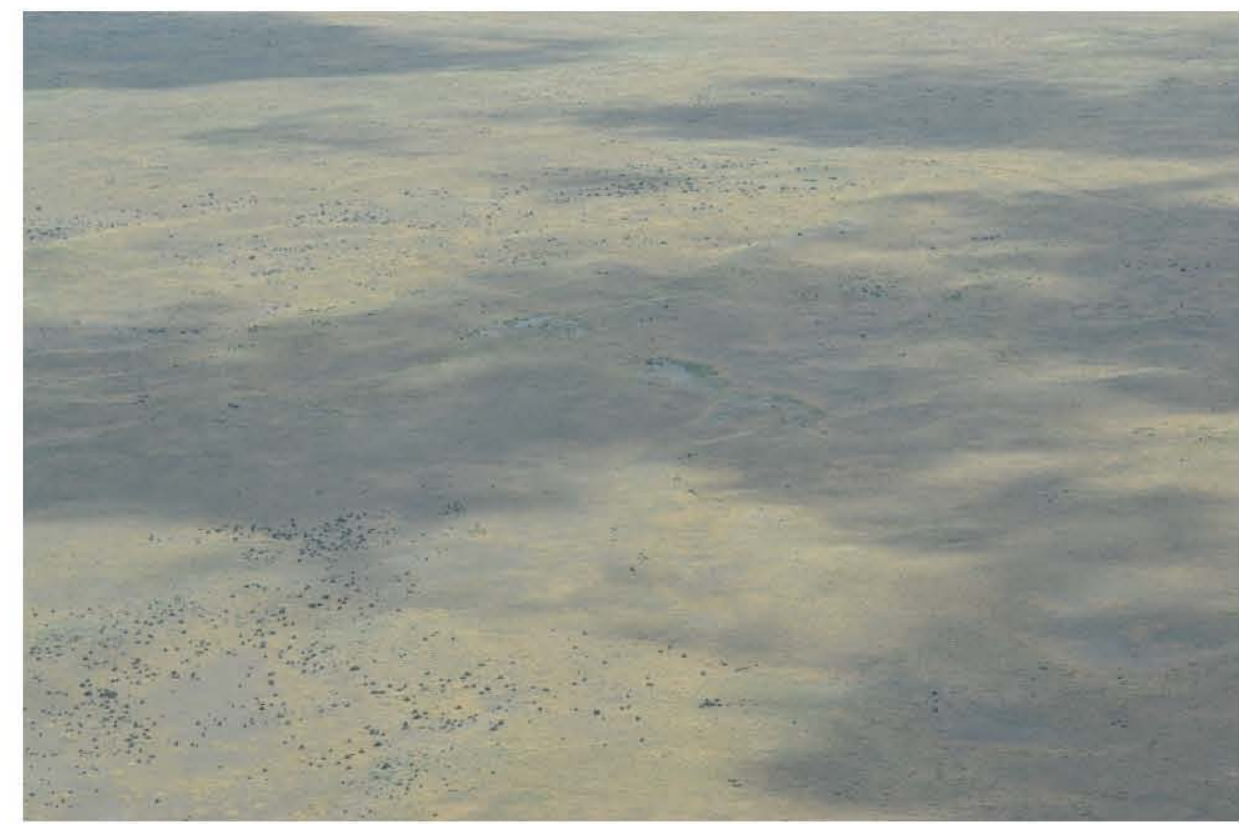

Figure 6. Optimal and sub-optimal viewing conditions during an aerial survey with patchy cloud cover

One of the purposes of the survey methodology chosen was to compare detectability between the aerial and ground survey methods, which were conducted simultaneously. Results of this comparison showed that the aerial survey was more likely to detect elk located far from roads and in open cover, while ground surveys were more likely to detect elk in dense cover (e.g. trees) and near roads. Although the Hanford Site is a mostly treeless open landscape, detection was likely less than $100 \%$, even with the combined aerial/ground surveys. Based on the incidental observation of 37 elk on $12 / 11 / 2012$, and the lack of any elk observations during the aerial/ground survey performed on $12 / 18 / 2012$, it is possible that the aerial/ground surveys failed to detect the relatively large herd of elk occupying the survey area.

This survey was designed to provide a relative abundance estimate of the elk using the central portion of the Hanford Site. The design included a relatively low level of effort, consistent with the level of detail 
required to answer the study questions. The aerial survey approach was designed to allow for the entire survey area to be observed during a single flight. This minimized the level of effort and costs associated with the project. However, in order to cover the survey area in a single flight (with a maximum time of approximately 2 hours), transects were spaced approximately two kilometers apart. With observers stationed on both sides of the airplane, each surveyor was responsible for the area from the center of the aircraft out to approximately 1000 meters (3281 feet). This method created a "blind spot" directly below the airplane, out to approximately 100 meters (321 feet) on each side. This resulted in surveyors observing approximately 900 meters (2953 feet) of the 1000 meters ( 3281 feet) during each pass, missing approximately $10 \%$ of the survey area overall. In order to avoid the "blind spot" problem, and increase the detectability of elk from the aerial survey, the transect spacing would need to be reduced from 2 kilometers to 1 kilometer ( 1.24 miles to 0.62 miles). Effectively, the survey effort would need to double in order to increase the percentage of area surveyed from $90 \%$ to $100 \%$, meaning two flights would be required. The resulting survey would likely increase the level of detection in the areas surveyed as well, giving surveyors multiple looks at areas from varying perspectives.

Out of the 17 observations of elk made during 2012, six occurred inside of the WDFW/FWS survey units (Figure 6), while the remaining 11 were outside of the survey units. Out of the 17 observations made in 2012, 16 of them occurred within the survey areas used for MSA's 2012 elk surveys (Figure 3).

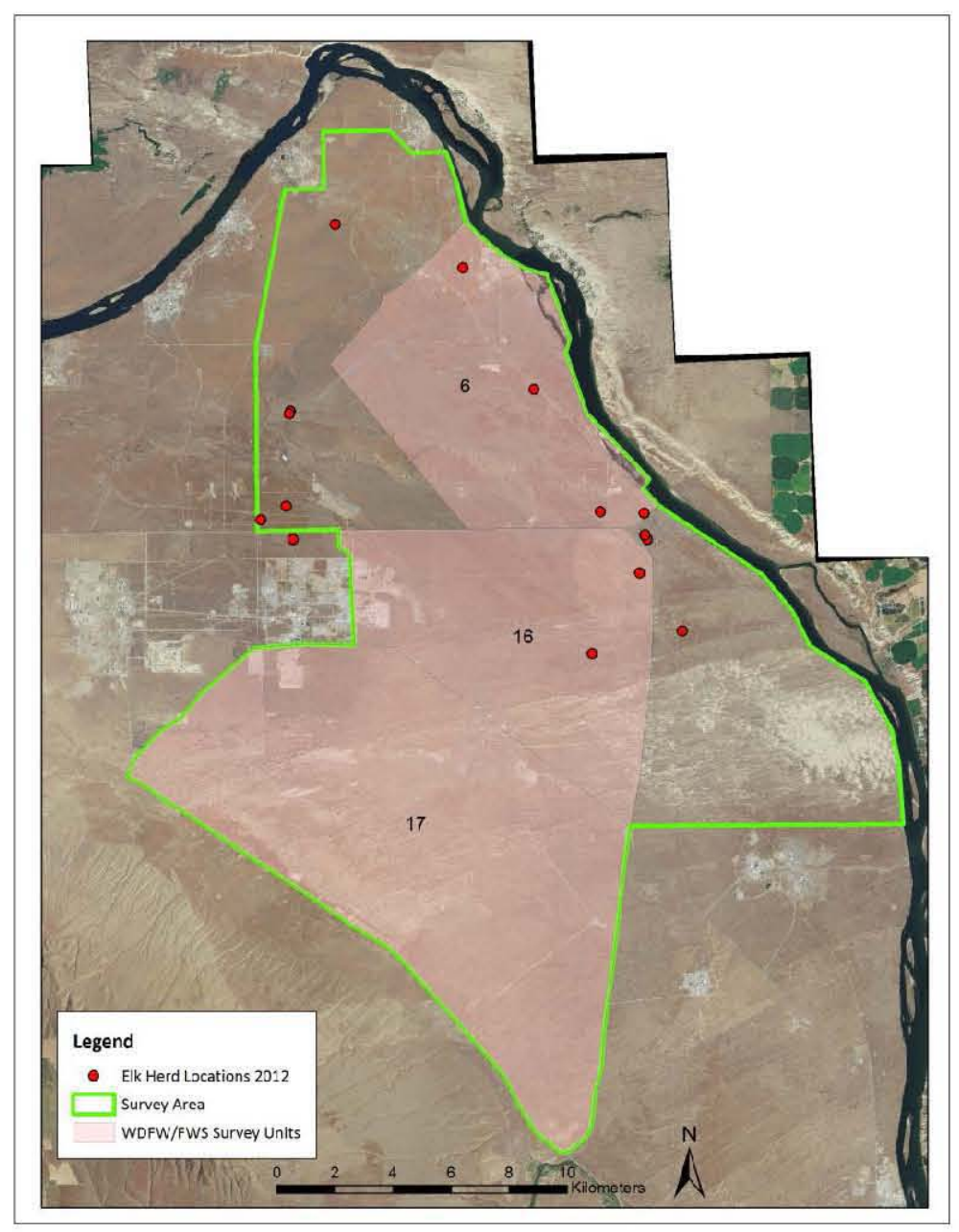

Figure 7.Elk herd locations on central Hanford during 2012. 
Despite elk hunting being delayed, elk numbers on the central Hanford Site appear to be increasing slowly, especially for antlerless elk. The maximum number observed in 2006 by the WDFW/FWS (Figure 7) included 44 bulls and only 6 cows. In addition to the bull herds that still frequent the central Hanford Site, herds of over 30 cows are now present regularly.

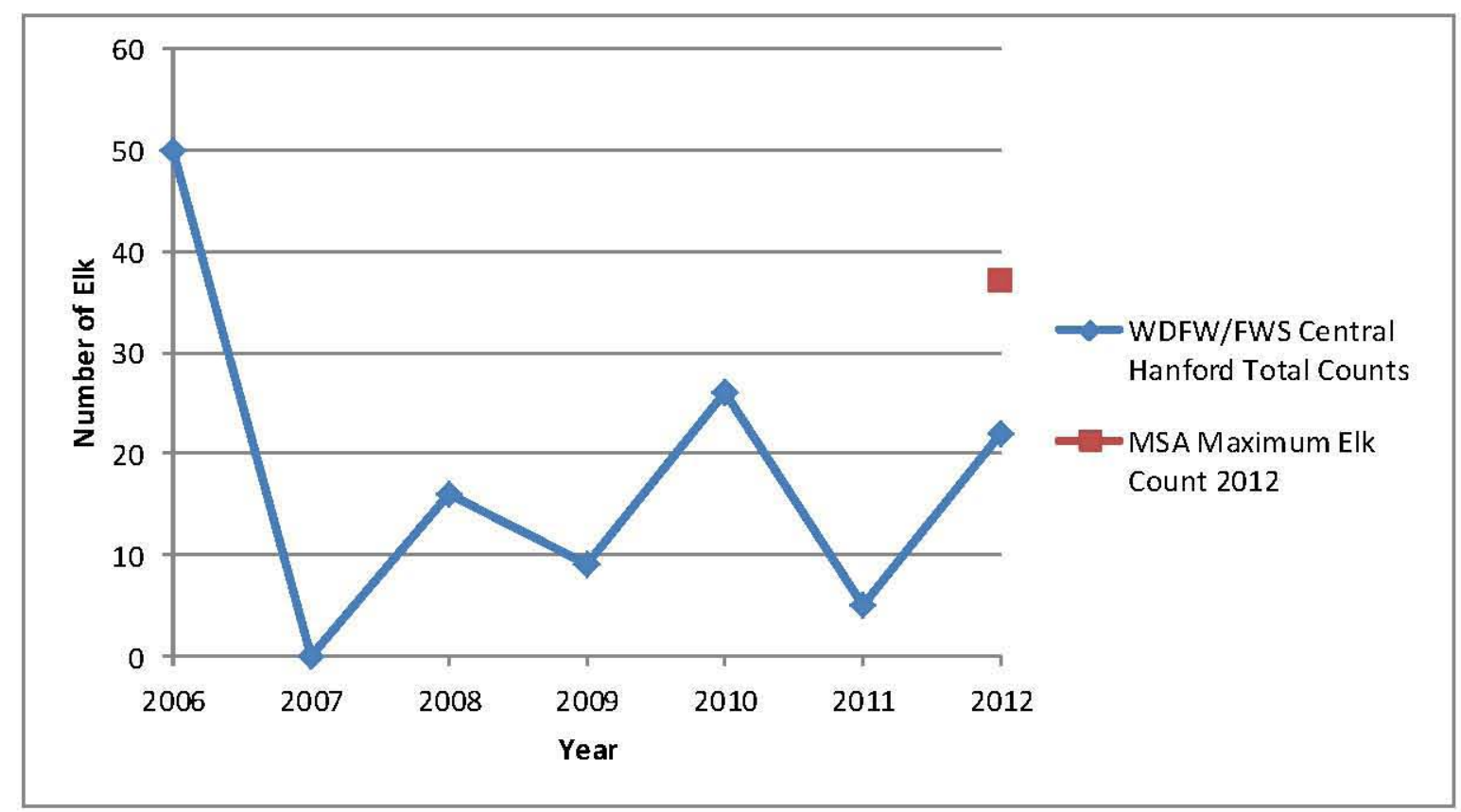

Figure 8. Maximum total elk counts for the WDFW/FWS counts and the 2012 MSA elk survey on central Hanford.

Out of the 17 elk observations recorded during 2012, 12 were made incidentally. MSA Ecological Monitoring Staff were instructed to document any elk observed while in the field performing other projects. This technique is biased to detecting elk near roads, and does not represent a consistent and dependable long-term survey methodology. However, incidental observations alone may be sufficient to maintain an ongoing record of the relative abundance of elk on central Hanford. Another limitation of the incidental observations is documenting a total number of elk using central Hanford. If multiple herds are present, or if herds break up and join back together, it can be difficult to establish a maximum elk number without one complete survey. A single annual aerial/ground survey could help to alleviate this problem.

As of the publication date of this report, elk hunting plans are still in development for the FEALE and no hunting has occurred and no hunt dates or tags have been released. If hunt plans continue to be delayed, it is expected that incidental observations, possibly combined with a single annual aerial/ground survey, may be sufficient to track the relative level of elk use on central Hanford. However, if hunting commences on the FEALE, additional elk specific surveys, including the more robust aerial protocol described above, would likely be necessary to more systematically and accurately track any changes in elk use of central Hanford relating to hunting activities. 


\subsection{References}

Draft Hanford Reach National Monument Elk Population Control Hunt Plan for the Arid Lands Ecology Reserve. 2011. United States Fish and Wildlife Service (FWSS), Burbank, Washington.

Eberhardt, L. E., L. L. Eberhardt, B. L. Tiller, and L. L. Cadwell. 1996. “Growth of an Isolated Elk Population," Journal of Wildlife Management (60)2:369-373.

Elk. 2012. Retrieved January 25, 2012 from http://www.fws.gov/hanfordreach/elk.html

McCorquodale, S.M. 1986. Elk Habitat Use Patterns in the Shrub-Steppe of Washington. J. Wildl. Manage. 50(4):664-669

McCorquodale, S. M., L. L. Eberhardt, and L. E. Eberhardt. 1988. Dynamics of a colonizing elk population. J. Wildl. Manage. 52:309-313.

Newsome, H. 2011. A Summary and Evaluation of the Sightability Survey for Rocky Mountain Elk on the Arid Lands Ecology Reserve unit of the Hanford Reach National Monument. United States Fish and Wildlife Service (FWSS), Burbank, Washington. Retrieved March 12, 2013 from http://www.fws.gov/hanfordreach/management.html

Tiller, B. T., L. L. Cadwell, R. K. Zufelt, L. Bender, S. Turner, G. K. Turner. 2000. Population Characteristics and Seasonal Movement Patterns of the Rattlesnake Hills Elk Herd-Status Report 2000. PNNL-13331. Pacific Northwest National Laboratory, Richland, Washington. Retrieved March 12, 2013 from http://www.pnl.gov/main/publications/external/technical reports/pnnl-13331.pdf 